\title{
Research on the Efficiency of China's Anti-monopoly Law
}

\author{
Lin Shi \\ College of Law and Humanities \\ TianJin Polytechnic University \\ Tianjin 300387, China \\ E-mail: shitou0126@yahoo.com.cn
}

\begin{abstract}
This paper focuses on the efficiency of China's new Anti-monopoly law. The monopoly enterprises seriously influence the equality of social distribution. In China, the "State-owned enterprises monopoly" is a controversial argument items. It has great influence on the efficiency of the anti-monopoly law enforcement. In this paper, this problem will be discussed.
\end{abstract}

Keywords: Anti-monopoly law, State-owned enterprises monopoly

\section{Background of China's Anti-monopoly law}

The monopoly enterprises seriously influence the equality of social distribution. It is reported that the annual salary of a meter-reading worker in a power station reached 100,000 RMB. A research shows that employees who work for the monopoly enterprises protected by special protection policies of the country government enjoy the income which is more than three times as much as the local average salary. Recent years, new profits have been from the oil, power, coal, and non-ferrous metal industries. On the other hand, poor services provided by some industries that hold "despot items" and "egoistic attitude" and this directly infringed on consumers' interests. As well known by Chinese people, China's two major mobile telecommunications giants depending on their monopoly position charged high inter-provincial roaming fee; interbrain banking service fee charged by banks; one-way phone charges has not realized; rising oil prices forced the private oil enterprises selling themselves to foreign companies; five power generation groups jointly released a letter to Development and Reform Commission and requested price increasing. Negative impacts on people's daily life make Chinese people and private enterprises long and expect the come-out of "anti-monopoly law".

In order to eliminate monopoly in these markets, protect the competition in the markets, maintain the market competition order, and make the market play full role in allocating resources, the Tenth National People's Congress Standing Committee 29th meeting of 2007 August 31 come out the anti-monopoly law and plan to carry out on August 1, 2008. Since then, this "anti-monopoly law", brewing from 1994, finally gave birth.

According to competition theory and industry economics, "effective monopoly" plays an important role in improving the development of economy. Therefore, the target of the anti-monopoly law should not aim at all monopoly enterprises but the monopoly and limit-competition behaviors. This conclusion comes from the hundred-year evolvement of western countries. The new anti-monopoly law aims at the monopoly and limit-competition behaviors, including: Monopoly operators reach an agreement; operator's abuse of market's dominant-position; operators who possibly obstacle competition, etc.

However, those industries that are concerning China's security and control position of state-owned economic status are protected by the government. The government protects their legitimate business activities and regulates their products and service price, protecting customers' interests, promoting technological advancement. In 2006, SAC issued "Guidance of promoting the restructuring and reorganization of state-owned enterprises" and first made a clear definition: The state capital should have the absolute control in the military industry, power grid electricity, oil, petrochemical, telecommunications, coal, civil aviation, shipping industry; the state capital should maintain "strong control" in the equipment manufacturing, automotive, electronic information, construction, steel, nonferrous metals, chemicals, survey and design, technology industries. 


\section{Penalties caused by improper monopoly of state-owned enterprises}

In those industries excepted by anti-monopoly law, not all of them are totally natural monopoly or belong to those industries that are should be controlled by the government under the state policies. As a result of not entirely natural monopoly industries and economic monopoly, phenomenon of restricting competition, lower socio-economic efficiency can be found everywhere. The "not entirely natural monopoly industries" indicates those industries that are operating unnatural monopoly business, for example, non-infrastructure segment of civil aviation industry and non-network facilities of telecommunication industry. Economy monopoly indicates large enterprises solely or jointly restrict, exclude and control economic activities in production and circulation domain, depending on their domination position and advantage position in the market (Yang Min, Wang Lijie, Zhang Yongan, 2002); administrative monopoly indicates such activities which come from the law and the government administration power and supported by the government, restricting competition in the market. Administrative monopoly is different from the traditional monopoly (natural monopoly, economy monopoly) and it originated from the economy transformation of China and Eastern European countries (Ke Jian, Zhang Xiao, 2006). According to China's present basic condition, administration monopoly has the most negative effects.

\subsection{Administrative monopoly can breed and foster corruption}

Behind administrative monopoly, there is always serious corruption, whether for political purposes or economic interests. The executive authorities and enterprises offer or accept bribes under the monopoly sectors, distributing national investment capitals and loans, and developing policies which are good for monopoly enterprises in price, tax and license, transferring people's interests to monopoly enterprises. Most of those enterprises are in the context of a government. The tax fees and part of profits are the main recourses of fiscal revenue. And therefore, in order to protect interests on their own, the administrative departments try their best to maintain the monopoly position of those industries. Consumers' interests in such circumstances are often ignored.

\subsection{It can lower socioeconomic efficiency}

Rent-seeking by enterprises and rent-setting by administrative departments can bring negative influence to social fortune and economic efficiency, damage social welfare and do harm to customers' interests. The executive authorities joint with monopoly enterprises become interest-community by setting regional and industry barriers, creating the largest interests for the enterprises they protect and bringing benefits from those enterprises. Such activities restrict effective competition seriously and lose the chance of enhancing productive efficiency and lowering cost. Take telecommunication industry for example, up to the end of last century, China's telecommunications switches amounted to about 170 million, more than the United States, forming a complete cable network. The use of program-controlled telephone proportion was as high as 99.8 percent. Long-distance transmission of digital was as high as 98.5 percent. The Modernization was beyond Australia and the USA.

However, due to China Telecom's price is always high, use of efficiency is lowered. China Telecom user is 1.4 times Germans, while German profits 2.8 times China's (Nie Xiaohong, 2007)

\subsection{Conflicts against national treatment system and the WTO}

National treatment system is an important system of WTO, enhancing fair competition by restricting activities of member countries. It is an important evidence for WTO, eliminating international barriers and building a union market. However, China's administrative monopoly is totally against anti-discrimination of National treatment system. In one word, it is an obstacle for China to pace the international economy development (Li Yong, 2001).

\section{Shortcomings in the implementation of the Anti-monopoly law}

Though the Anti-monopoly law aims at eliminating the disadvantages of improper monopoly and breaking the low social efficiency caused by long-term monopoly, shortcomings in the implementation of the Anti-monopoly law resulted from the monopoly by administrative power and state-owned enterprises still exist.

\subsection{Taking public's interests as excuse}

The first principle in the profile of the Anti-monopoly law indicates the target of this Law: preventing and suppressing monopolies, protecting the free market, improving economic efficiency and safeguarding the consumers' interests and social public interests, and promoting the healthy development of the socialist market economy. So parts of enterprises can be protected for the reason of "safeguarding the consumers' interests and social public interests" Take the seventh principle in the profile for example: "As for state-owned and controlled industries relating to the lifeline of the national economy and national securities and industries carrying out franchise activities by law, the government will offer the protection to their legal operating activities and supervise and regulate the price of their products and services, protecting consumers' interests and promoting technological progress". However, "social public interests" is an ambiguous concept, which gives a most rational reason. 


\subsection{Lack of effective anti-monopoly law enforcement agencies}

\subsubsection{Two-tier system of multi-agency law enforcement system}

The law enforcement system designed by the Anti-monopoly law is a "Two-tier system of multi-agency law enforcement system", including an Anti-monopoly committee and several Anti-monopoly law enforcement agencies. The Anti-Monopoly Committee plays a role in organizing, coordinating and guiding anti-monopoly work. In general, the authority of law must be derived from an independent, centralized, unified, professional law enforcement system and law enforcement agencies. Therefore, comparing with other countries' experience, we can clearly find some unforeseen problems lying in our law enforcement system.

If there is a clear delineation of the border settled among law enforcement agencies, once the economic monopoly occurred, different law enforcement departments will fell over each other with executing the law when it refers to more benefits and different law enforcement departments will be in mutual prevarication when it involves more difficulties of law enforcement. As mater of fact, the "Two-tier system of multi-agency law enforcement system" dismembered the law enforcement power which should have been controlled by one agency. This leads to the low efficiency of the implement of the Anti-monopoly law. Such a law enforcement system will hard to take effect unless the Anti-Monopoly Committee can do good job in their duty and set a positive authority and strictly regulate each law enforcement agencies.

\subsubsection{Lack of the special powers on regulatory bodies}

The Anti-monopoly law prohibits abuse of dominating market position and it should concern those large enterprises that have made a monopoly or dominant market position, particularly in telecommunications, postal services, railways, electricity, banking and other areas of large state-owned monopolies. However, in general, however, in general, these large state-owned monopoly sectors of the industry have regulatory bodies, whether the anti-monopoly law enforcement agencies have the power to regulate these industries is a sensitive topic. Therefore, if the "anti-monopoly law" does not have special power on the regulatory body, law enforcement will be interfered by these regulatory bodies.

\subsubsection{Administrative Monopoly in the legislative process}

In the legislative process, "Administrative Monopoly" is always a controversial topic. And in Feb., 2006, it was reported that chapters about "Anti- Administrative Monopoly" were canceled from the Anti-monopoly law. As media reported, on a feasibility study meeting in Dec., 2005, the discussion focused in "Anti- Administrative Monopoly" was very serious. In the end, ideas of "eliminating reform" were accepted. "Eliminating reform" indicates that the Anti-monopoly law should focus on "Anti-economic monopoly" but not "Administrative Monopoly" and "Administrative Monopoly" must be eliminated by advanced system reform. "Anti-administrative Monopoly" is not the job of "Anti-monopoly Law". (Wang Xiaoye, 2007).

So at present, the immediate "Anti-monopoly Law" doses not play a part in eliminating administrative monopoly in China. It should depend on the process of perfecting the market economy system to realize.

\section{Conclusion and suggestions}

Thus, to sum up, we are still anxious about the efficiency of the new Anti-monopoly law. In reference to the principles themselves, there is large room to explain. As for the efficiency of law enforcement, there is not a united, authorized and indecent anti-monopoly law enforcement agency. And the government's spoiled attitude to state-owned enterprises influences the efficiency of Anti-monopoly law enforcement.

While we can not generalize that all the monopoly of state-owned enterprises should be eradicated, because in some monopolized industries the benefits to society are often larger than the damage caused by limiting competition. However, for improper monopoly of state-owned enterprises, such as administrative monopoly, if not to be eliminated, the risks and hidden dangers will not disappear. There is nothing wrong with the strong support of state-owned enterprises to enlarge its scale, but the government always pursues the policy of the state-owned enterprises and this will in fact weakened the strength of the growth of state-owned enterprises, making these state-owned enterprises like the fragile flowers in the greenhouse.

There are some suggestions on realizing anti-monopoly in China:

Firstly, the targets should be known clearly. The government should opposed activities of state-owned enterprises.

Secondly, a strong, united, authorized and indecent anti-monopoly law enforcement agency should be set up. It is an assurance to the efficiency of the anti-monopoly law enforcement.

Thirdly, competition should be brought into the monopoly industries. To really make the market mechanism work, companies reduce costs and improve quality, improve management, positive innovation, and so as to achieve greater efficiency, optimize the allocation of resources, the most fundamental way is to introduce a full, fair, sequent competition into monopoly industries. 
Finally, the public power is very important. It is far from enough to depend on government. Making use of propaganda means, so that citizens can clearly understand the harm and significance of anti-monopoly. It will play a positive role in promoting anti-monopoly.

\section{References}

Guo, Yong \& Hu, Angang. (2003). Administrative Monopoly ---One of the Most Serious Corruption Forms in Chinese Economical Transition Period. Honest and Clean Government, 5, 13-15.

Ke, Jian \& Zhang, Xiao. (2006). Compare and Re-analyze the Concept of Anti-monopoly. Modern Management Science, 8, 45-47.

Li, Yong. (2001). The Analysis and Enlightenment on the Conflicts between China's Administrative Monopoly and the National Treatment of WTO. Journal of International Trade, 2, 18-20.

Nie, Xiaohong. (2007). The Necessity of Bringing Administrative Monopoly into China's Anti-monopoly Law. Hebei Legal Science, 2, 32-35.

Wang, Xiaoye.(2007). Four "Bottlenecks" of the Implementation of Anti-monopoly Law. Finance Economics, 12, 25-28.

Yang, Ming, Wang Lijie \& Zhang Yongan. (2002). The Viewpoints on Chinese Legislation of Anti-monopoly. Contemporary Law Review, 10, 24-26. 